ISSN 0258-7122 (Print), 2408-8293 (Online)

Bangladesh J. Agril. Res. 42(2): 233-247, June 2017

\title{
UTILIZATION OF SPECIALIZED AGRICULTURAL CREDIT ON ONION AND GARLIC CULTIVATION IN SELECTED AREAS OF BANGLADESH
}

\author{
M. KHATUN ${ }^{1}$, TANVIR M. B. Hossain, S. KHANDOKER ${ }^{1}$ \\ M. E. A. BEGUM ${ }^{2}$ AND A. F. M. S. ANOWAR ${ }^{3}$
}

\begin{abstract}
Specialized Agricultural Credit (SAC) policy implemented by the Bangladesh Bank played a significant role to increase agricultural production specially spices. But documentation in this regard is scarce in Bangladesh. Therefore, this study captured the impacts of specialized credit on onion and garlic cultivation at Faridpur and Natore district respectively. The survey was conducted on two hundred farmers of which fifty were credit recipient farmers and fifty were nonrecipient farmers of each district. Credit recipient farmers received on an average Tk. 26,255 for spices cultivation. Average cost to complete the process from receiving to repaying credit was Tk. 515. Farmers in the study areas utilized their maximum part of credit for spices cultivation $(96.2 \%)$ followed by other crop cultivation $(2.15 \%)$, family expenditure $(1.4 \%)$ and business $(0.25 \%)$. Due to getting credit facility farmers cultivated 16 decimals more land compared to previous years for spices, $42 \%$ of the farmers increased number of spices crop for cultivation, and farmers also increased amount of input use with better quality. For these, credit recipient farmers harvested spices with higher yield which finally helped in getting higher farm income. Credit recipient farmers received $7 \%$ higher net return from onion and $16 \%$ higher net return from garlic cultivation. Highest percentage of farmers (82\%) mentioned that lack of information about spices credit was the main reason behind not receiving credit facility by large number of farmers. Specialized credit facility for farmers need to be widened through spreading information of spices credit facility among the farmers and increasing amount of credit.Therefore, domestic production of spices will increase and imports of spices from abroad will decrease.
\end{abstract}

Keywords: Specialized agricultural credit, onion, garlic, impact, utilization pattern and spices production.

\section{Introduction}

Agricultural credit is considered as one of the strategic resources for increasing the crop production consequently raises the living standard of our rural poor farming community. When farmers faced capital constraints the amounts and combinations of inputs used may deviate from optimal levels that can hamper the optimum production. Therefore, the contribution of credit brings input levels

\footnotetext{
${ }^{1 \& 2}$ Scientific Officer and Senior Scientific Officer, Agricultural Economics Division, Bangladesh Agricultural Research Institute (BARI), Gazipur, ${ }^{3}$ Lecturer, Department of English, BMTTI, Gazipur, Bangladesh.
} 
closer to the optimal levels and increases yield and output (Feder et al., 1990).Timely and easy access to credit enables farmers (including marginal farmers) to purchase the required inputs and machinery for carrying out farm operations and increase production (Abedullah, 2009; Saboor et al., 2009).

Spices have a great popularity in Bangladesh. The major spices grown and consumed in Bangladesh are onion, garlic, chilli, ginger, coriander, turmeric, black cumin and fenugreek. In Bangladesh, the total cultivated land under spices cultivation is 3.25 lakh hectares and production is 17.56 lakh tons (BBS, 2012). This production is not available to meet the demands of Bangladeshi people. According to the Department of Agriculture Extension (DAE), Bangladesh imports about $50 \%$ of its total consumption of spices and annualy about Tk. 25 billion is expensed for import payment. Among the spices, production, consumption and import of onion and garlic are higher. Area of onion and garlic in Bangladesh are 1.36 lakh and 0.44 lakh hectares and production are 11.59 lakh and 2.34 lakh tons respectively which are comparatively more than other spices (BBS, 2012).

Realizing this situation, Bangladesh government has taken initiative to reduce the import of spices by increasing domestic production. The government decided to give subsidy to the banks at $6.0 \%$ of the amount of their special argil-credit disbursement to enable them to get an aggregate of $10 \%$ as rate of interest by disbursing such credit to the farmers. The credit is being given to discourage import of the items and thus reduce the amount of their import payment. In this perspective, Bangladesh Bank disbursed credit for SAC (import alternative crops such as pulse, oilseed, spices and maize) but in a small amount. In fiscal year 2013, Bangladesh Bank has disbursed Tk. 146.67 billion for agricultural credit in which only Tk. 0.75 billion was for SAC which was $0.51 \%$ of total agricultural credit (BB, 2013). The government re-fixed $4.0 \%$ rate of interest in the previous fiscal (2011-12), in place of the earlier rate of $2.0 \%$, on specialized agricultural credit, to be disbursed for cultivation of pulses, oil seeds, spices and maize.

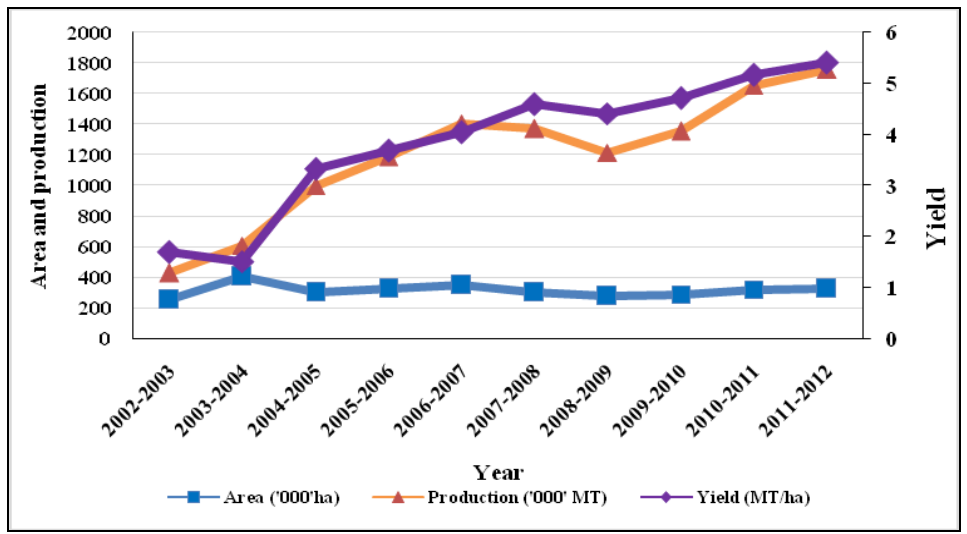

Fig. 1. Area, production and yield of spices in Bangladesh, 2002-03 to 2011-12. Source: Various issues of BBS. 


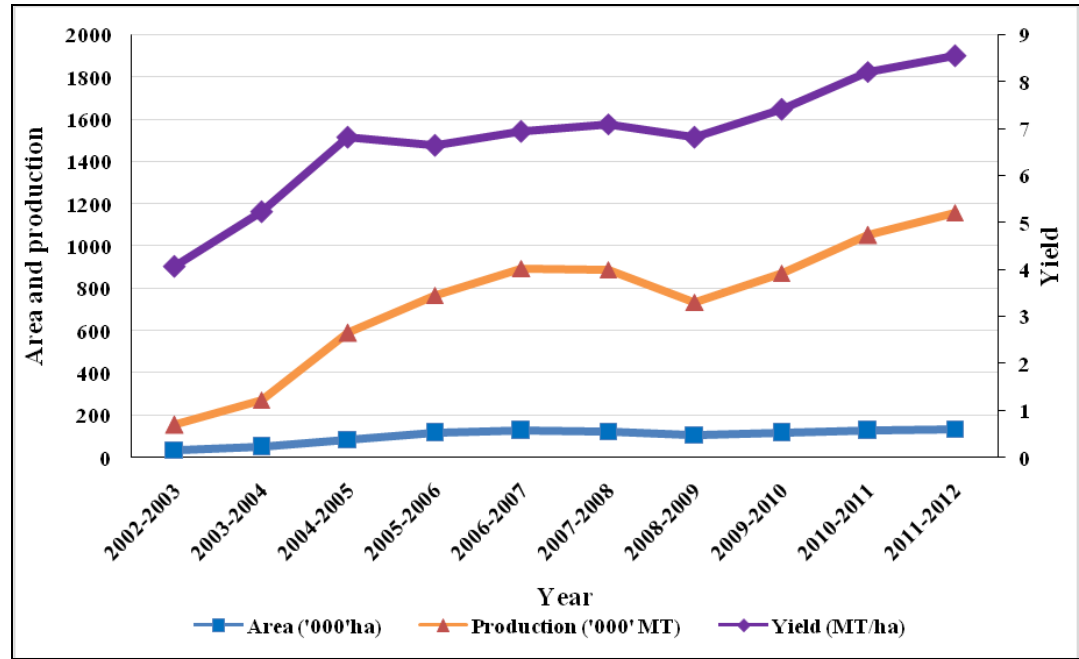

Fig. 2. Area, production and yield of onion in Bangladesh, 2002-03 to 2011-12. Source: Various issues of BBS

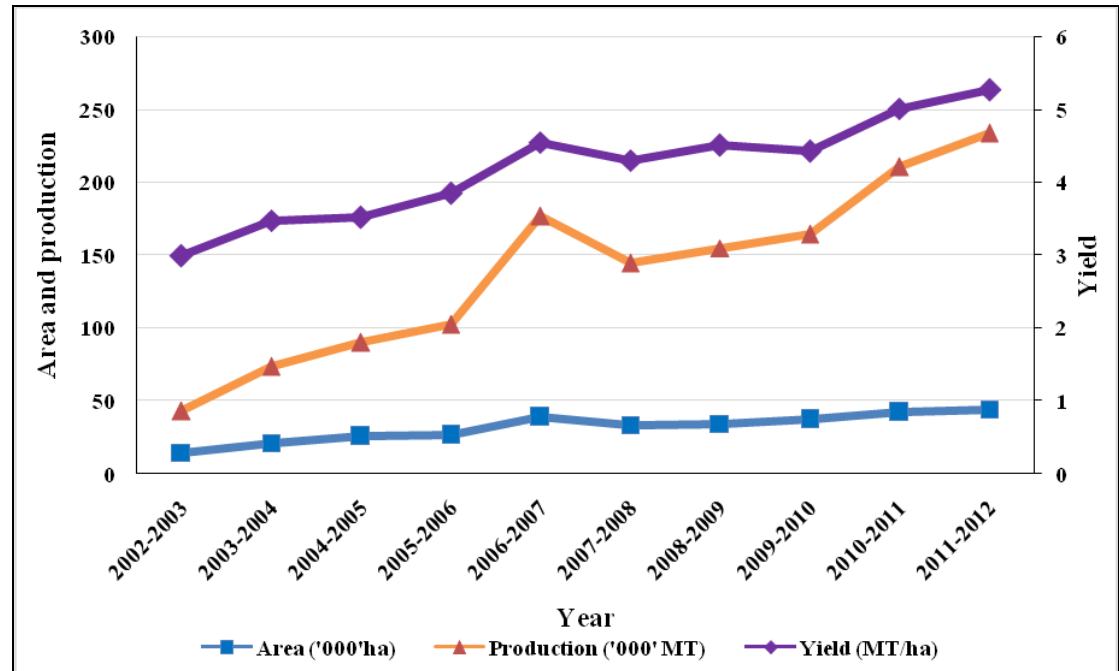

Fig. 3. Area, production and yield of garlic in Bangladesh, 2002-03 to 2011-12.

Source: Various issues of BBS.

Owing to taking government initiative (special credit programme on spices cultivation), farmers are gradually becoming more and more interested in cultivating spices, availing the credit facility on easy terms and thus, the area and production of spices are increasing year after year (Fig. 1). Area and production of onion and garlic are also increasing year after year (Figs. $2 \& 3$ ).

For further improvement of the credit policy on spices production it is necessary to evaluate the efficiency of credit recipient farmers and productivity of spices. 
Therefore, the present study was undertaken to evaluate the performance of agricultural credit policy for spices (onion and garlic) production with the following objectives.

\section{Objectives}

The objectives of this study were as follows.

i. To explore the utilization pattern of specialized credit for spices cultivation;

ii. To measure the impacts of specialized agricultural credit on spices cultivation;

iii. To find out the limitations of access to specialized agricultural credit; and

iv. To suggest policy options for the improvement of credit policy.

\section{Methodology}

\subsection{Description of the study areas}

Faridpur and Natore districts were purposively selected according to the high intensity of onion and garlic production (BBS, 2012). Nagorkanda upazila from Faridpur and Gurudaspur upazila from Natore district were selected according to the availability of specialized credit users.

\subsection{Sampling technique}

A multi-stages sampling procedure was followed to collect sample farmers for this study.Two spices crops, namely onion and garlic were purposively selected for this study. Fifty credit recipients in spices production was selected from each upazila. An equal number of credit non-recipients (50) were also selected from each district for the sake of comparison. Thus, the total number of respondents was 200 .

\subsection{Period of the study}

The study was mainly based on primary data collection through face to face interview which was conducted through field survey during the month of February to March 2014.

\subsection{Analytical techniques}

The collected data were edited and managed to fit with proposed analytical technique of the study. Descriptive statistics such as averages and percentages were used in this study. Profitability of onion and garlic was analyzed to compare the return received by the credit recipient and non-recipient farmers. To measure the significant difference between recipient and non-recipient farmers $\mathrm{Z}$ - test was used. 


\section{Measurement of cost and return from crop cultivation}

Equations for cost analysis were as follows:

$$
\begin{aligned}
& T C_{i j}=T V C_{i j}+T F C_{i j} \\
& T V_{i j}=V C_{i j}+10 C_{i j} \\
& V C_{i j}=\sum_{l=1}^{n} X_{i j} P_{i j} \\
& I O C_{i j}=\left(A I_{i j} \mathrm{x} r \mathrm{x} t\right)
\end{aligned}
$$

Where, $\mathrm{TC}_{\mathrm{ij}}=$ Total cost $(\mathrm{Tk} / \mathrm{ha})$

$\mathrm{TVC}_{\mathrm{ij}}=$ Total variable cost $(\mathrm{Tk} / \mathrm{ha})$

$\mathrm{TFC}_{\mathrm{ij}}=$ Total fixed cost $(\mathrm{Tk} / \mathrm{ha})$

$\mathrm{VC}_{\mathrm{ij}}=$ Variable cost $(\mathrm{Tk} / \mathrm{ha})$

$\mathrm{IOC}_{\mathrm{ij}}=$ Interest of operating capital (Tk/ha)

$\mathrm{X}_{\mathrm{ij}}=$ Quantity of inputs

$\mathrm{P}_{\mathrm{ij}}=$ Price of inputs

$A I=($ Total investment $) / 2$

$\mathrm{r}=$ Rate of interest

$\mathrm{t}=$ Length of crop period in months

$\mathrm{j}=$ Number of crops (Garlic and Onion)

$\mathrm{i}=$ Number of farmers $(1.2 .3 \ldots \ldots \ldots \mathrm{n})$

Equation for profitability analysis

Gross Return $=\mathrm{GR}_{\mathrm{ij}}-\mathrm{Y}_{\mathrm{ij}} \mathrm{P}_{\mathrm{ij}}$

Net return $=G_{\mathrm{ij}}-\mathrm{TC}_{\mathrm{ij}}$

Gross margin $=\mathrm{GR}_{\mathrm{ij}}-\mathrm{VC}_{\mathrm{ij}}$

Where,

$$
\begin{aligned}
& \mathrm{GR}_{\mathrm{ij}}=\text { Gross return }(\mathrm{Tk} / \mathrm{ha}) \\
& \mathrm{P}_{\mathrm{ij}}=\text { Price }(\mathrm{Tk} / \mathrm{ha}) \text { of } j \text { th crops received by } i \text { th farmer } \\
& \mathrm{Y}_{\mathrm{ij}}=\text { Quantity }(\mathrm{kg} / \mathrm{ha}) \text { produced from crops }
\end{aligned}
$$

\section{Results and Discussion}

\subsection{Receiving and Utilization Pattern of Spices Credit}

Amount of credit received by the recipient farmers: Highest percentage of farmers received credit within the range of Tk. 6,000 to Tk. 20,999 and their average received money was Tk. 14,631 (Table 1). The average amount of credit was Tk. 26,255. The highest percentage of Faridpur farmers received on an average Tk. 14,879 whereas it was Tk. 28,475 for Natore farmers. 
Table 1. Amount of credit taken by the farmers

\begin{tabular}{c|c|c|c|c|c|c}
\hline \multirow{2}{*}{$\begin{array}{c}\text { Range of credit } \\
\text { received (Tk.) }\end{array}$} & \multicolumn{2}{|c|}{ Faridpur } & \multicolumn{2}{c|}{ Natore } & \multicolumn{2}{c}{ Average } \\
\cline { 2 - 7 } & $\begin{array}{c}\text { Amount } \\
\text { (Tk.) }\end{array}$ & $\begin{array}{c}\text { Recipient } \\
(\%)\end{array}$ & $\begin{array}{c}\text { Amount } \\
(\text { Tk. })\end{array}$ & $\begin{array}{c}\text { Recipient } \\
(\%)\end{array}$ & $\begin{array}{c}\text { Amount } \\
(\text { Tk. })\end{array}$ & $\begin{array}{c}\text { Recipient } \\
(\%)\end{array}$ \\
\hline $6000-20999$ & 14879 & 58 & 14077 & 26 & 14631 & 42 \\
$21000-35999$ & 28214 & 28 & 28615 & 52 & 28475 & 40 \\
$36000-50999$ & 42200 & 10 & 43750 & 16 & 43154 & 13 \\
$51000-65999$ & 60000 & 4 & 60500 & 4 & 60250 & 4 \\
$66000-80999$ & - & - & 70000 & 2 & 70000 & 1 \\
Grand Total & 23150 & 100 & 29360 & 100 & 26255 & 100 \\
\hline
\end{tabular}

Types of collateral ensured by the recipient farmers: It is revealed that highest percentage of farmers provided the document or record of their own land as collateral for getting spices credit (Table 2). As farmers of Faridpur district applied for credit personally, 98\% of them provided own land record as collateral for credit. Farmers of Natore managed spices credit through forming a groupso, sometimes they didn't need any collateral for getting credit.

Table-2: Types of collateral keeping in bank by the farmer

\begin{tabular}{l|c|c|c}
\hline \multirow{2}{*}{\multicolumn{1}{c}{ Types of Collateral }} & \multicolumn{2}{c|}{ Recipient $(\%)$} & Total Recipient \\
\cline { 2 - 4 } & Faridpur & Natore & $(\%)$ \\
\hline 1. Own land record & 98 & 90 & 94 \\
2. Rented in land record & - & 4 & 2 \\
3. No collateral was needed & 2 & 6 & 4 \\
Grand Total & 100 & 100 & 100 \\
\hline
\end{tabular}

Cost of credit: Credit recipient farmers in the study areas also paid some extra money to complete the process fromreceiving to repaying credit. Highest cost of credit was Tk. 614 in Natore district and average cost was Tk. 515 (Table 3). Highest percentage of cost (30\%) for credit was spent in deed purpose, $22 \%$ of cost for collateral preparation, and also spent $16 \%$ for transportation. Another cost of credit was for revenue stamp (10\%), form charge (9\%) and others purpose (13\%).

Table 3. Cost associated with the entire process of getting to repayment credit

\begin{tabular}{l|c|c|c|c|c|c}
\hline \multirow{2}{*}{ Cost items } & \multicolumn{2}{c|}{ Faridpur } & \multicolumn{2}{c|}{ Natore } & \multicolumn{2}{c}{ All farmers } \\
\cline { 2 - 7 } & Amount (Tk.) & $\%$ & Amount (Tk.) & $\%$ & Amount (Tk.) & $\%$ \\
\hline 1. Deed purpose & 123 & 28 & 174 & 28 & 153 & 30 \\
2. Collateral preparation & 89 & 21 & 162 & 26 & 111 & 22 \\
3. Transportation cost & 74 & 17 & 95 & 15 & 84 & 16 \\
4. Revenue stamp & 50 & 12 & 50 & 8 & 50 & 10 \\
5. Form charge & 26 & 6 & 70 & 11 & 48 & 9 \\
6. Others & 70 & 16 & 63 & 10 & 69 & 13 \\
Total & 432 & 100 & 614 & 100 & 515 & 100 \\
\hline
\end{tabular}


Farmer's acceptance of extra cost for getting credit: Every credit service has some amount of necessary charges which is given by the credit receiver. The farmers of the study areas mentioned that they also spent some money as service charge for receiving the credit (Table 4). In question of acceptability of the service charges, $55 \%$ of recipient farmers mentioned that the service charge was at acceptable range. But requiring extra expenses was less acceptable mentioned by $22 \%$ of recipient and unacceptable mentioned by $23 \%$ of farmers.

Table 4. Acceptability of extra expense to get credit

\begin{tabular}{l|c|c|c}
\hline \multirow{2}{*}{\multicolumn{1}{c}{ Acceptability }} & \multicolumn{2}{c|}{ Recipient (\%) } & Total \\
\cline { 2 - 4 } & Faridpur & Natore & Recipient (\%) \\
\hline Acceptable & 50 & 60 & 55 \\
Less acceptable & 14 & 30 & 22 \\
Unacceptable & 36 & 10 & 23 \\
Grand Total & 100 & 100 & 100 \\
\hline
\end{tabular}

Credit utilization pattern of the farmers: Farmers utilized their capital in different purposes. It is revealed that farmers in the study areas utilized their maximum part of credit for spices cultivation (96.2\%) followed by other crop cultivation $(2.15 \%)$, a family expenditure $(1.4 \%)$ and business $(0.25 \%)$. Both the farmers of Faridpur and Natore districts also utilized their credit in a same pattern (Table 5). To make the appropriate use of credit Rahman et al. (2010) suggested that agricultural credit should be advanced at the beginning of crops farming, livestock and poultry raring, fish farming etc. and repayment should be made after getting returns from the investment. In this study, farmers got credit at the beginning of the crops cultivation and they had utilized their capital properly.

Table 5. Spices credit utilization pattern (\%)

\begin{tabular}{l|c|c|c|c|c}
\hline \multicolumn{1}{c|}{ District } & $\begin{array}{c}\text { Spices } \\
\text { cultivation }\end{array}$ & $\begin{array}{c}\text { Others crop } \\
\text { cultivation }\end{array}$ & $\begin{array}{c}\text { Family } \\
\text { expenditure }\end{array}$ & Business & Total \\
\hline Faridpur & 95.2 & 3.6 & 1.2 & - & 100 \\
Natore & 97.2 & 0.7 & 1.6 & 0.5 & 100 \\
All farmers & 96.2 & 2.15 & 1.4 & 0.25 & 100 \\
\hline
\end{tabular}

\subsection{Overall Impacts of Spices Credit}

\subsubsection{Change in sources of working capital}

\section{Share of capital source used by the recipient farmers}

Farmers of Bangladesh suffer from lack of capital for crop cultivation. Providing credit facility helps them significantly to overcome this problem and invest the money for crop cultivation efficiently and timely. When the farmers suffered from lack of capital they managed the capital from various source. The farmers of the study area also did the same before getting credit facility from the government. The study explored that before getting credit facility the spices farmers managed $58.75 \%$ of their capital from the income of other crop 
cultivation, $17.7 \%$ from off-farm income, and $14.55 \%$ from saving of agriculture (Table 6). Farmers managed only $2.8 \%$ of capital from borrowed money and $0.4 \%$ from NGOs. This indicated that, income and savings from agriculture of a farmer contributed largely to manage capital for the next crop cultivation when a farmer couldn't get any kind of credit.

Farmer's share of capital source changed largely after getting credit for spices cultivation. It is revealed that farmers managed $49.85 \%$ of required capital from the credit, and $36.8 \%$ of capital from other crop cultivation income. Their percentage share of borrowed money was also changed and reduced from $2.8 \%$ to $0.35 \%$ (Table 6 ).

Table 6. Share of capital sources used in spices cultivation of recipient farmers

\begin{tabular}{l|c|c|c|c|cc}
\hline \multirow{2}{*}{ Sources of capital $(\%)$} & \multicolumn{3}{c|}{ Before getting credit } & \multicolumn{3}{c}{ After getting credit } \\
\cline { 2 - 7 } & Faridpur & Natore & Total & Faridpur & Natore & Total \\
\hline 1. Spices credit & - & - & - & 48.9 & 50.8 & 49.85 \\
2. Income from other crops & & & & & & \\
$\quad$ cultivation & 50.7 & 66.8 & 58.75 & 34.4 & 39.2 & 36.8 \\
3. Income from off-farm activities & 15 & 20.4 & 17.7 & 7.4 & 5.4 & 6.4 \\
4. Savings from agriculture & 20.1 & 9 & 14.55 & 4.8 & 3.8 & 4.3 \\
5. Savings from off-farm activities & 9.8 & 1.8 & 5.8 & 3.6 & 0.8 & 2.2 \\
6. Borrowed money from others & 4.4 & 1.2 & 2.8 & 0.7 & - & 0.35 \\
7. Other agricultural credit & - & - & - & 0.2 & - & 0.1 \\
8. NGO credit & - & 0.8 & 0.4 & - & - & - \\
Total & 100 & 100 & 100 & 100 & 100 & 100 \\
\hline
\end{tabular}

Share of capital source used by the non-recipient farmers: The source of capital managed by the non-recipient farmers revealed that $51.15 \%$ of the capital was sourced from other crop cultivation income and $16.15 \%$ of capital was from offfarm activities. Non-recipient farmers borrowed money to cover $4.35 \%$ of their required capital and take credit from NGOs to cover $2.5 \%$ of the capital. Some farmers also bought required inputs with credit which shared $3.95 \%$ of the required capital (Table 7).

Table 7. Share of capital source used in spices cultivation of non-recipient farmers

\begin{tabular}{llcc|c}
\hline \multirow{2}{*}{ Sources of capital (\%) } & \multicolumn{2}{|c|}{ Non-recipient } & \multirow{2}{*}{ Total Non-recipient } \\
\cline { 3 - 4 } & Faridpur & Natore & \\
\hline 1. Income from other crops cultivation & 44.5 & 57.8 & 51.15 \\
2. Income from off-farm activities & 16.8 & 15.5 & 16.15 \\
3. Savings from agriculture & 18.7 & 13.7 & 16.2 \\
4. Savings from off-farm activities & 9.6 & 2 & 5.8 \\
5. Borrowed money & 4 & 4.7 & 4.35 \\
6. Buy input in credit & 2.2 & 5.7 & 3.95 \\
7. NGO credit & 3.7 & 0.6 & 2.15 \\
8. Agricultural credit & 0.5 & 0 & 0.25 \\
Total & 100 & 100 & 100 \\
\hline
\end{tabular}




\subsubsection{Proper utilization of spices income}

Distribution of income from spices cultivation: Spices farmers spent large share of their spices cultivation income for other crop cultivation (29\%) and family purpose (29\%). The major share of the rest of the income was allocated for the spices crop cultivation (28\%). Credit recipient farmers used $12 \%$ of their income to repay the credit. Both the farmers of Faridpur and Natore had similar expenditure pattern of spices cultivation income (Table 8).

Table 8. Percentdistribution of income from spices cultivation

\begin{tabular}{|c|c|c|c|c|c|c|c|}
\hline \multirow[t]{2}{*}{ Income distribution } & \multicolumn{2}{|c|}{ Recipient } & \multirow{2}{*}{$\begin{array}{c}\text { Total } \\
\text { Recipient }\end{array}$} & \multicolumn{2}{|c|}{ Non-recipient } & \multirow{2}{*}{$\begin{array}{c}\text { Total } \\
\text { Non- } \\
\text { recipient }\end{array}$} & \multirow{2}{*}{$\begin{array}{c}\text { All } \\
\text { farmers }\end{array}$} \\
\hline & Faridpur & Natore & & Faridpur & Natore & & \\
\hline a. Spices cultivation & 22 & 36 & 29 & 23 & 32 & 27 & 28 \\
\hline b. To repay credit & 15 & 9 & 12 & 6 & 3 & 4 & 8 \\
\hline c. Other crops cultivation & 33 & 31 & 32 & 32 & 21 & 27 & 29 \\
\hline d. Family expenditure & 26 & 21 & 24 & 33 & 34 & 34 & 29 \\
\hline e. Other expenditure & 4 & 3 & 3 & 6 & 10 & 8 & 6 \\
\hline Total & 100 & 100 & 100 & 100 & 100 & 100 & 100 \\
\hline
\end{tabular}

\subsubsection{Increase in input use and spices productivity}

A significant change was observed in the farm economy especially due to having credit facility for spices cultivation. The impact of getting credit was observed through counting change in the farming and economy. Highest percentage of farmers $(85 \%)$ mentioned that the yield of spices increased due to getting credit facility. After getting credit facility, $23 \%$ farmers increased amount of fertilizer use, $18 \%$ of farmers' increased labour use, and $17 \%$ of farmers increased amount of quality seed use on their land (Table 9). Due to increasing spices yield and getting higher return, $72 \%$ of farmers mentioned that their family income also increased.

Table 9. Changes apparent in input use and productivity of spices after getting

\begin{tabular}{l|c|c|c}
\multicolumn{1}{c}{ Changes } & \multicolumn{2}{c|}{ Recipient } & \multirow{2}{*}{ Total Recipient } \\
\cline { 2 - 3 } & Faridpur & Natore & \\
\hline 1. Increased use of input (\%) & & & \\
a. Fertilizer & 24 & 22 & 23 \\
b. Labour & 26 & 10 & 18 \\
c. Quality seed & 24 & 10 & 17 \\
d. Irrigation & 6 & 10 & 8 \\
e. Others & - & 6 & 3 \\
2. Increased yield (\%) & 88 & 82 & 85 \\
3. Increased family income (\%) & 60 & 82 & 72 \\
\hline
\end{tabular}




\subsubsection{Increase in spices area and production}

Credit recipient farmers have increased on an average 16 decimal of land under spices cultivation. $42 \%$ of farmers mentioned that due to getting credit they increased number of spices crops for cultivation. Highest percentage of farmers $(32 \%)$ introduced garlic in to current cropping pattern, $14 \%$ of farmers cultivated onion (Table 10). A small percentage of farmers started to cultivate black cumin, coriander, and turmeric. Most farmers of Faridpurand Natorecultivated onion and garlic respectively due to getting credit facility. This indicated that the objective of providing special credit facility to the farmers was fulfilled to a great extent. Farmers were encouraged to cultivate spices on their land.

Table 10. Farmers increased spices cultivation area and production after getting credit facility

\begin{tabular}{l|cc|c}
\hline \multirow{2}{*}{\multicolumn{1}{c|}{ Particulars }} & \multicolumn{2}{c|}{ Recipient } & \multirow{2}{*}{ Total Recipient } \\
\cline { 2 - 3 } & Faridpur & Natore & \\
\hline 1. Increased land (decimal) & 13.67 & 18.29 & 15.98 \\
2. Increased number of spices (\%) & 38 & 46 & 42 \\
Name of spices (\%) & & & \\
Garlic & 28 & 32 & 16 \\
Onion & & & 14 \\
Black cumin & 4 & 4 & 2 \\
Coriander & 2 & & 2 \\
Coriander, Black cumin & 2 & & 1 \\
Coriander, Black cumin, Fenugreek & 2 & & 1 \\
Garlic, Black cumin & & 2 & 1 \\
Onion, Coriander, Black cumin & & 2 & 1 \\
Onion, Garlic & & 4 & 1 \\
Onion, Black cumin & & 2 & 2 \\
Turmeric & 38 & 46 & 1 \\
Total responses (\%) & & & 42 \\
\hline
\end{tabular}

\subsubsection{Increase in spices income}

\section{Returns and profitability of credit ingarlic cultivation}

Profitability of garlic production: Due to using comparatively higher inputs in production, credit recipient farmers have got higher yield $(7563 \mathrm{~kg} / \mathrm{ha})$ of garlic than non-recipient farmers $(6970 \mathrm{~kg} / \mathrm{ha})$ where have significant differences $(\mathrm{Z}=$ $3.02, p=0.001)$. Gross return of credit recipient farmers was Tk. 3, 24,798 and non-recipient farmers was Tk. 2, 9,697 (Table 11). 
Table 11. Per hectare profitability of garlic cultivation for recipient and nonrecipient farmers

\begin{tabular}{|c|c|c|c|c|c|}
\hline Particulars & Recipient & $\begin{array}{c}\text { Non- } \\
\text { recipient }\end{array}$ & $\begin{array}{l}Z \text {-test } \\
\text { value }\end{array}$ & P-value & Results \\
\hline A. Yield $(\mathrm{Kg} / \mathrm{ha})$ & 7563 & 6970 & 3.02 & 0.001 & Difference \\
\hline B. Price $(\mathrm{Tk} / \mathrm{kg})$ & 42.95 & 42.78 & 0.20 & 2.501 & No difference \\
\hline C. Gross return (Tk.) & 324798 & 296976 & 1.98 & 0.040 & Difference \\
\hline D. Total variable cost (Tk.) & 192469 & 182240 & 3.27 & 0.001 & Difference \\
\hline E. Gross margin (C-D) & 132328 & 114736 & 1.59 & 0.180 & No difference \\
\hline F. Fixed Cost (Tk.) & 23729 & 23153 & 1.01 & 0.389 & No difference \\
\hline G. Total cost $(\mathrm{D}+\mathrm{F})$ & 216198 & 205393 & 3.33 & 0.001 & Difference \\
\hline H. Net return $(C-G)$ & 108600 & 91583 & 2.20 & 0.023 & Difference \\
\hline I.BCR on cash cost $(C \div D)$ & 1.69 & 1.63 & 0.095 & 8.052 & No difference \\
\hline J. BCR on full cost $(C \div G)$ & 1.513 & 1.459 & 0.79 & 1.032 & No difference \\
\hline K. Production Cost $(\mathrm{Tk} / \mathrm{kg})$ & 25.70 & 26.31 & -0.72 & 1.015 & No difference \\
\hline L. Profit per kg & 17.25 & 16.47 & 1.05 & 0.356 & No difference \\
\hline M. Returns to credit & 13.59 & & & & \\
\hline
\end{tabular}

There was a significant difference of gross returns between the two groups $(\mathrm{Z}=1.98, \mathrm{p}<0.05)$. Credit recipient farmers received on an average Tk. 1,08,600 as net return which was higher compared to non-recipient farmers (Tk.91,583) and there is also have a significant difference $(Z=2.20, p<0.05)$.This higher return was due to higher yield of the produce. BCR on both full cost and cash cost basis was higher in recipient farmers but there was no significant difference between the two groups of farmers. There was no significant difference in profit per $\mathrm{kg}$ between the recipient farmers (17.27 Tk.) and non-recipient farmers (16.47 Tk.). Credit recipient farmers received Tk. 13.59 as return from the utilization of one taka credit.

\section{Returns and Profitability of Credit in Onion Cultivation}

Profitability of onion cultivation: Due to using comparatively higher inputs in production, credit recipient farmers had got higher yield $(14136 \mathrm{~kg} / \mathrm{ha})$ than non-recipient farmers $(13,232 \mathrm{~kg} / \mathrm{ha})$ showing significant differences $(\mathrm{Z}=2.96$, $\mathrm{p}=0.010)($ Table-12). Gross return of credit recipient farmers was Tk. 5,99,184 and non-recipient farmers was Tk. 5,64,290 (Table-12). There was a significant difference of gross returns between the two groups $(Z=2.03, p<0.05)$. Credit recipient farmers received on an average Tk. 4,07,910 as net return which was higher compared to non-recipient farmers (Tk. 3,79,026) and there is also have a significant difference $(\mathrm{Z}=2.49, \mathrm{p}<0.05)$. This higher return was due to higher yield and higher price of the onion. BCR on both full cost and cash cost basiswas higher in recipient farmers but there was no significant difference between the two groups of farmers. There was no significant difference in profit per $\mathrm{kg}$ between the recipient farmers (Tk. 30.61) and non-recipient 
farmers (Tk. 30.22). Credit recipient farmers received Tk. 32.08 as return from the utilization of one taka credit.

Table 12. Per hectare profitability of onion cultivation for recipient and nonrecipient farmers

\begin{tabular}{lcccccc}
\hline \multicolumn{1}{c|}{ Particulars } & Recipient & $\begin{array}{c}\text { Non- } \\
\text { recipient }\end{array}$ & $\begin{array}{c}\text { Z-test } \\
\text { value }\end{array}$ & P-value & Results \\
\hline A. Yield (Kg/ha) & 14136 & 13232 & 2.96 & 0.010 & Difference \\
B. Price (Tk/kg) & 42.90 & 42.70 & 0.09 & 8.052 & No difference \\
C. Gross return (Tk.) & 599184 & 564290 & 2.03 & 0.039 & Difference \\
D. Total variable cost (Tk.) & 173185 & 165789 & 2.45 & 0.023 & Difference \\
E. Gross margin (C-D) & 426000 & 398501 & 2.37 & 0.026 & Difference \\
F. Fixed Cost (Tk.) & 18089 & 19475 & -2.50 & 0.020 & Difference \\
G. Total cost (D+F) & 191274 & 185264 & 2.01 & 0.042 & Difference \\
H. Net return (C-G) & 407910 & 379026 & 2.49 & 0.020 & Difference \\
I. BCR on cash cost(C $\div \mathrm{D})$ & 3.46 & 3.40 & 1.45 & 1.002 & No difference \\
J.. BCR on full cost(C $\div \mathrm{G})$ & 3.16 & 3.06 & 1.35 & 1.002 & No difference \\
K.Production Cost (Tk/kg) & 12.29 & 12.48 & -0.57 & 5.062 & No difference \\
L.Profit per kg & 30.61 & 30.22 & 0.05 & 8.630 & No difference \\
M. Returns to credit & 32.08 & & & & \\
\hline
\end{tabular}

\subsection{Limitations of access to specialized agricultural credit and farmers' perceptions on its improvement}

Limitations of access to credit: Non-recipient farmers mentioned various reasons of not getting credit from the bank (Table 13). Highest percentage of farmers $(87 \%)$ mentioned they did not know about the credit giving facility as a main reason of not getting credit. $30 \%$ of farmers mentioned that they couldn't enlist their name in the credit list. $22 \%$ of farmers mentioned that they don't have communication with the UAO for this they didn't get credit. The other reasons mentioned by some farmers were they didn't have any need to take credit $(8 \%)$, they didn't receive credit due to its complex system (6\%), didn't have ability to keep collateral (3\%), couldn't manage to include their name in the group (3\%), didn't want to pay interest (2\%).

Farmers' perceptions on credit policy improvement: Providing credit facility to the farmers had very significant positive impact on the farm economy. There is no doubt that capital support is the most effective support for the farmers to improve their main source of income from agriculture. But still there were some gaps and problems in the widening of credit facility among the farmers. Farmers were suggested some policy reform options to remove the gap and problems in credit facility which need to be counted for its further improvement. 
Table 13. Reasons of not getting spices credit

\begin{tabular}{l|c|c|c}
\hline \multirow{2}{*}{\multicolumn{1}{c|}{ Reasons }} & \multicolumn{2}{c|}{ Non-recipient $(\%)$} & Total \\
\cline { 2 - 4 } & Faridpur & Natore & Non-recipient \\
\hline 1. Lack of knowledge about spices credit & 88 & 86 & 87 \\
2. Couldn't enlist name to the credit list & 22 & 38 & 30 \\
3. Don't have Communication with UAO & 26 & 18 & 22 \\
4. No need of taking credit & 8 & 8 & 8 \\
5. Complexity in taking credit & 6 & 6 & 6 \\
6. Have no ability to keep collateral in bank & 6 & 0 & 3 \\
7. Couldn't include in a group & 0 & 6 & 3 \\
8. Didn't want to pay interest & 2 & 2 & 2 \\
\hline
\end{tabular}

Table 14. Farmers' perceptions on specialized agricultural credit policy improvement

\begin{tabular}{|c|c|c|c|}
\hline \multirow{2}{*}{ Options } & \multicolumn{2}{|c|}{ Recipient (\%) } & \multirow{2}{*}{$\begin{array}{c}\text { Total } \\
\text { Recipient }\end{array}$} \\
\hline & Faridpur & Natore & \\
\hline $\begin{array}{l}\text { 1. Widespread broadcast of specialized bank credit by } \\
\text { bank }\end{array}$ & 52 & 22 & 37 \\
\hline 2. Bank should need work properly & 20 & 10 & 15 \\
\hline 3. Should increase time of repayment & 22 & 8 & 15 \\
\hline $\begin{array}{l}\text { 4. Increase the amount of credit } \\
\text { (according to land size or production cost) }\end{array}$ & - & 28 & 14 \\
\hline 5. Should make the system easy for giving credit & 2 & 20 & 11 \\
\hline 6. Should increase monitoring of bank credit by BB & 12 & 8 & 10 \\
\hline 7. Increase the number of recipient & 8 & 10 & 9 \\
\hline 8. Have to reduce reference facility of UP chairman & 8 & 8 & 8 \\
\hline 9. Broadcasting bank credit facility by government & 14 & 2 & 8 \\
\hline 10. Should make yearly repayment system & 12 & 2 & 7 \\
\hline 11. Introducing collateral free credit & - & 14 & 7 \\
\hline 12. SAAO should inform farmer directly about credit & - & 12 & 6 \\
\hline 13. UAO should work actively to disseminate information & 8 & - & 4 \\
\hline 14. Need to reduce cost of Deed Promissory Note (DPN) & - & 6 & 3 \\
\hline 15. Repayment yearly only interest not principal amount & - & 4 & 2 \\
\hline 16. Introducing system of one time DPN cost & - & 2 & 1 \\
\hline
\end{tabular}

Highest percentage of farmers (37\%) suggested publicising the special credit facility information among the farmers (Table 14). It is identified in this study that the main reason of not getting credit by the non-recipient farmers was lack of 
information of credit facility. The study reveals that, $15 \%$ farmer suggested improving credit giving facility of the bank, $15 \%$ farmers suggested to increase repayment time and $14 \%$ farmers suggested increasing amount of credit according the farm size of a farmer. Farmers also suggested to many other option for the improvement of the credit facility given by the government i.e. need to make the system easy for the farmers, need to strengthen central bank monitoring system to evaluate the outcome of providing credit facility to the farmers, the bank authority should reduce referencing facility from the UP chairman. The other farmers suggested options are presented in the (Table 14).

The non-recipient farmers also suggested some options to increase number of recipient of this specialized credit facility. Highest percentage of farmers $(43 \%)$ suggested that the credit giving system need to be more easy and flexible (Table15). Another $43 \%$ farmers suggested that the authority should introduce interest free credit for the poor farmers and $14 \%$ farmers suggested to widen the information of special credit facility among the farmers. This indicated that farmers need more easy system of getting credit, lower or zero interest rate credit and finally they need to have that information on their hand so that they can take decision to receive any credit when they need.

Table 15. Credit non-recipient farmers' demand in improving the credit policy

\begin{tabular}{l|c|c|c}
\hline Options & Faridpur & Natore & Total Non-recipient \\
\hline Should make easy the system of giving credit & - & 75 & 43 \\
Introducing Interest free credit system & 100 & - & 43 \\
Popularization of specialized credit by bank & - & 25 & 14 \\
\hline
\end{tabular}

\section{Conclusions and Recommendations}

Specialized credit facility for the spices farmers has created a wide range of impacts among the farmers. Due to getting credit facility farmers increased their cultivable land for spices cultivation, increased number of spices crop for cultivation, increased input use in quantity and quality. For these, the yield of cultivated spices increased in the farmer's field which finally increased the income of farmers. Net return of credit recipient farmers for both crops was higher. Most of farmers mentioned lack of information about spices credit as a reason behind not getting credit. According to the farmers' perceptions credit facility for farmers can be widen through spreading information of spices credit facility among the farmers and increase amount of credit.

Since this policy has positive impacts on the increasing of area and production of spices, Bangladesh bank and government authorities should increase the total amount of credit under specialized credit scheme. To increase the number of farmers under this credit policy, government and banks should take initiatives to disseminate the information about special credit facility for spices cultivation among the farmers. Bank should increase the amount of credit according to the 
land size or production cost. Credit disbursement system should make easy and transparent. Bank should disburse collateral free credit and repayment system should be yearly. If these initiatives are undertaken each farmer would get opportunities of receiving more amounts and the number of beneficiaries will also be increased. Therefore, domestic production of spices will increase and imports of spices from abroad will decrease which is the ultimate goal of this specialized credit policy.

\section{References}

Abedullah. N. M., M. Khalid and S. Kouser. 2009. The role of agricultural credit in the growth of livestock sector: a case study of Faisalabad Pakistan. Vet. J. 29(2): 81-84.

BB. 2013. Annual Report FY 2013, Bangladesh Bank, Bangladesh.

BBS. 2012. Bangladesh Bureau of Statistics, Statistical Year Book of Bangladesh, Statistics Division, Ministry of planning, Government of People's Republic of Bangladesh, Dhaka.

Feder, G., L. Lau, J. Lin and X. Luo. 1990. "The Relationship between Credit and Productivity in Chinese Agriculture: A Microeconomic Model of Disequilibrium." American Journal ofAgricultural Economics 72(5): 1151-1157.

Rahman M. W., J. Luo and E. Cheng. 2010. Policies and performances of agricultural/rural credit in Bangladesh: what is the influence on agricultural production? African Journal of Agricultural Research. 6(31). Pp. 6440-6452.

Saboor A, Hussain M, Munir M (2009). Impact of micro credit in alleviating poverty: An Insight from rural Rawalpindi, Pakistan, Pak. J. Life Soc. Sci. 7(1): 90-97. 
